attitude of local authorities seemed rather paradoxical. By the award of scholarships they encouraged their ablest scholars to carry on their education till they were too old to have a chance of entering the service of the authorities." Inter-departmental committees in Whitehall have investigated the situation and made valuable recommendations-but nothing has been done to open up a real road from the universities to the local and municipal services other than that long enjoyed by the technicians, for example, medical men or engineers.

\section{Science at the British Industries Fair}

The visit of H.M. The King to the British Industries Fair at Olympia and the White City on February 19 was the first public function which he attended since his accession to the throne. At Olympia he spent some time in the Scientific Instrument Section and inspected the principal exhibits, especially the epidiascopes, microscopes and binoculars. His Majesty expressed his appreciation of the fine display of instruments and of the general lay-out of the grouped stands, for the organisation of which the Scientific Instrument Manufacturers' Association of Great Britain was responsible. This year there were a greatly increased number of buyers from overseas, among whom representatives from Continental countries were predominant, and many of the leading scientific instrument firms report that, through the Fair, they have established valuable connexions in the markets of the Continent and elsewhere.

\section{Romano-British Cave Burial in Yorkshire}

Some interesting questions are raised in the report by Sir Arthur Keith on human skeletal remains discovered last year in a cave in Kingscar, near Langcliffe, Yorkshire. The implements and weapons associated with the remains, according to a statement accompanying the report in The Times of February 24, are of Romano-British date. A detailed account of the artefacts will be given when the investigation of the cave, which is being carried out by members of the Pig Yard Club, is complete; but in the meantime Sir Arthur reports that the skeletal material submitted to him consists of the skeleton of a man, from which certain parts are missing, and fragments of at least four individuals, of whom one is a girl, one a man, and two, or possibly three, are women. The portions missing from the main burial, which was in the extended position, suggest to Sir Arthur that there has been a partial disturbance across the lower part of the body, which brought about the simultaneous removal of the missing parts. He is, however, at a loss to account for the appearance, both here and elsewhere in caves, of the fragmentary remains; though he is disinclined to regard them, as do some authorities, as evidence of the survival of cannibalism in Britain to so late a date. It will be interesting to see how far the detailed stratigraphic evidence supports the natural presumption of disturbance. It is unfortunate that the missing parts include both the thighbones; but on the evidence of the left tibia, which has survived, the stature has been calculated as five feet five inches. In the measurements which have been made, the most marked feature is the length of the head, which gives the low cranial index of $69 \cdot 3$. In general character, the remains suggest a population comparable to the late Celtic (Romano-British) population of the west of Britain.

\section{Huskless Oats}

So many letters are reaching the National Institute of Agricultural Botany asking for information about huskless oats that Sir Rowland Biffen has prepared a brief account of them. These oats differ from our ordinary varieties in two important respects. The first is that the thin, paper-like husks surrounding the grain do not grip it tightly, with the result that, on threshing, the naked grains are set free just as those of wheat are. The second is that they have some six or seven grains in each spikelet instead of the usual two or three. These grains are loosely strung on a stalk sufficiently long for two or three to protrude and hang down well below the glumes. As the result of this exposure, considerable losses from shattering may be expected in unfavourable harvesting conditions. It is responsible, too, for giving the standing crop the appearance of being very high yielding. But this expectation is not realised on threshing any more than is the expectation that a barley with six rows of grain must out-crop one with two rows only. Most of the huskless oats now in existence come from China, where several distinct forms are in cultivation, but though these have been tried out in many countries during the past half century, their range of cultivation has not increased to any extent. Of late years experimenters have paid a great deal of attention to these Chinese oats. Apparently none of these experimenters, although it is an important part of a plant breeder's work to assess the agricultural value of the material he collects, has seen fit to recommend the general cultivation of huskless oats. One English firm of seedsmen, famous throughout the world for the cereal varieties which it has bred and distributed, has for the past forty years used strains of naked oats for crossing with many varieties of the ordinary cultivated oats. Two years ago the firm abandoned this work, having become convinced that the chances of obtaining any derivative of outstanding agricultural value were negligible.

\section{Recent Acquisitions at the Natural History Museum}

Among the donations received by the Zoological Department during the last month have been two collections of Indian game trophies, presented by Lieut.-General Sir Henry Keary and Lieut.-Colonel Sir Armine Brereton Dew. The first of these collections consists of a number of mounted heads, mostly from Burma, while the second comprises a number of skulls and horns of Kashmir sheep, markhor and ibex. Eleven hundred specimens of birds, collected by the late Capt. Boyd Alexander in Central and West Africa, have been acquired from his heir. Capt. 